\title{
Modern Anarchism in Social Movements
}

\author{
From the Arab Spring to the Occupy \\ Wall Street Movement
}

Clifford Baverel ${ }^{1}$

\begin{abstract}
[Abstract] Since its launch in 2011, the Occupy Wall Street movement has been linked with anarchist theory and practice by several scholars such as David Graeber, Nathan Schneider, and Mark Bray. However, Occupy was not an isolated case in the history of social movements. It emerged at a paroxysmal point as anti-neoliberal and prodemocracy manifestations - both local and global - have already been flourishing throughout the end of the $20^{\text {th }}$ century. In a few years, demonstrations, uprisings, and social protests spread all around the world in the global North and the global South. It went from the Arab Spring in 2011 to the Greek protests, the Indignants, the OWS and the Gezi Park movement in 2013. This article aims to study the presence of anarchist ideas and practices in these early 2010 s movements. To do so, we rely on existing studies dealing with the political and economic aspects of these movements. We argue that if anarchism is linked with the 2010 s movements, it is through its political and economic values and practices. As a matter of fact, the period that preceded - from the mid-1990s until 2010 - already witnessed the development of anti-neoliberal, alterglobalization and pro-democracy movements. Thus the central point of contestation which characterizes these movements - which can be referred to as $3^{\text {rd }}$ wave movements - are indeed political and economic. The empirical studies that were analysed in this article may not all point out a link between these movements and anarchism but show, at least, the practice of political and economic alternatives than can be defined as anarchistic - close to the anarchist ideas without clearly mentioning it. The anarchist ideas and practices observed in the 2010s movements thus show a link with the re-emergence of anarchism, under the form of post-anarchism, since the mid1990s. Its development is closely related to the rise of the alter-globalization movement. Under its new form anarchism tends to distance itself from its violent past in the $19^{\text {th }}$ century. Even though it is not referred to as "anarchism" in mainstream media, it still exists through new movements such as alter-globalization and direct democracy experiments.
\end{abstract}

Keywords modern anarchism, post-anarchism, Arab Spring, Occupy, alter-globalisation, $3^{\text {rd }}$ Wave Movements.

[Résumé] Le mouvement Occupy Wall Street, depuis ses débuts en 2011, a été relié à la théorie et à la pratique anarchiste par différents universitaires tels que David Graeber, Nathan Schneider et Mark Bray. Cependant, Occupy n'est pas un cas isolé dans I'histoire des mouvements sociaux. Le mouvement s'est développé à un moment où

1 Doctorant à l'Université d'Angers. 
les manifestations des courants anti-néolibéral et pro-démocratie - à la fois locales et mondiales -, qui étaient apparues à la fin du XXe siècle, ont atteint un point culminant. En quelques années, des manifestations, des révoltes et des protestations sociales se sont répandues à travers le monde, au Nord comme au Sud. Cela va des printemps arabes en 2011 au mouvement de Gezi Park en 2013, en passant par les protestations en Grèce, le mouvement des Indignés et Occupy Wall Street. Cet article s'intéresse à la présence d'idées et de pratiques anarchistes au sein de ces mouvements, apparus au début des années 2010. II s'appuie sur des études qui portent sur les aspects politicoéconomiques de ces mouvements. On pose comme hypothèse que si l'anarchisme est lié aux mouvements des années 2010 c'est au travers de ses valeurs et de ses pratiques politiques et économiques. En effet, la période qui précède les mouvements des années 2010 - -qui s'étale du milieu des années 1990 jusqu'en 2010 - a vu le développement des mouvements anti-néolibéral, altermondialiste et pro-démocratie. Ainsi, le point de contestation central qui caractérise ces mouvements - que l'on qualifiera de mouvements de la $3^{\mathrm{e}}$ vague - est donc bien politico-économique. Les études empiriques utilisées comme base de travail pour cet article ne montrent pas toutes de façon explicite le lien qui existe entre ces mouvements et l'anarchisme, mais elles révèlent cependant l'usage de pratiques politiques et économiques alternatives qui peuvent être considérées comme anarchisantes - proches des idées anarchistes sans le mentionner clairement. La présence d'idées et de pratiques anarchistes au sein des mouvements des années 2010 montre ainsi un lien avec la réémergence de l'anarchisme, sous la forme du post-anarchisme, depuis le milieu des années 1990 et dont le développement est étroitement lié au mouvement altermondialiste. Sous cette nouvelle forme, l'anarchisme a tendance à s'éloigner de son passé violent du XIXe siècle. Ainsi, même si l'anarchisme n'est pas mentionné comme tel dans la presse grand public, il existe au travers de nouveaux mouvements tels que l'alter-mondialisme et les expériences de démocratie directe.

Mots clés : anarchisme contemporain, post-anarchisme, Printemps arabes, Occupy, alter-globalisation, mouvements de la $3^{\mathrm{e}}$ Vague.

\section{Introduction}

At the end of the 1970s and during the 1980s, global capitalism took a new direction which became known as neoliberalism. Associated with the end of the cold war, it enabled the development of a globalized type of capitalism (Smith, 2012: 370-372). Under the influence of the economic theories of Milton Friedman and Friedrich Hayek, U.S. President Ronald Reagan and U.K. Prime Minister Margaret Thatcher carried out neoliberal policies aiming at disengaging the state from the private sector. The result was a "laissez-faire" policy, which was very advantageous for Big Business Companies. Since then, the critics against the economic system have been called indiscriminately anti-liberalism or anti-capitalism. Neither of which terms will be used in the present article. Instead, we shall have recourse to the term "anti-neoliberalism" to avoid confusion between Economic Liberalism and Liberalism in the United States.

By the end of the $20^{\text {th }}$ century, opposition to neoliberalism had grown so strong it leads to the launching of a global movement in Seattle, in 1999, as a response to the 
World Trade Organization (WTO) summit. The movement attracted thousands of activists from various labour unions - some organized in the Direct Action Network (DAN) - and non-governmental organizations (NGOs). The relationship between the activists and the authorities became confrontational and the federal government had to mobilize the National Guard. From that moment on, movements of alter-globalization emerged. It has to be noted that the roots of alter-globalization, defined as a social movement that opposes globalized capitalism, can be traced back to the 1960s. However, the rapid spreading of ideas and methods of alter-globalization at a continental and global level was later made possible through the organization of several G7 and G8 counter-summits as well as the launching of the World Social Forums (WSF). Initiated in 2001, the WSF is an annual meeting of organizations and activists whose main goal is to oppose global neoliberalism. It shows the re-emergence of a global participation in the early $21^{\text {st }}$ century social movements.

The movements that emerged from the end of the $20^{\text {th }}$ century until the 2010 s did not have a majority of participants advocating anarchism. However, this article argues that anarchist ideology has been present in all of these movements. An emphasis will be put on the economic and political sides of the anarchist ideology. Politically, anarchism advocates a rejection of representative democracy to the benefit of a more direct democracy, under a horizontal type of political organization from the bottom up. Economically, it defends an anti-capitalist position and suggests a more local and community-based organization. Modern anarchism, or post-anarchism, compared to $19^{\text {th }}$-century anarchism, has changed its practice and has developed new tools and new means of action. Syndicalism, for instance, is much weaker than it used to be. Anarchists had a strong presence within unions at the time, so much that it was later called anarchosyndicalism. The diminishing number of factory workers in the northern countries caused syndicalism's, and, in the meantime, anarcho-syndicalism's decline. Post-anarchism relies more on small local independent groups organized around a specific purpose and interconnected thanks to social media. Its definition of the concept of revolution has also evolved to become the addition of small local achievements. Because of this change, modern anarchism may not be identified at first sight when traces of it are found in the social movements of the $3^{\text {rd }}$ wave.

The arguments developed here focus on recent movements, from the Arab Spring in 2011 until the Occupy movement in 2012 and 2013. Scholars such as Mohammed A. Bamyeh, in Egypt, have made the connection between anarchism and the Arab Spring, which is not always obvious. Relations between Occupy and anarchism, on the other hand, are clearer. Several works have been made to link both movements, the main ones being: Noam Chomaky's Occupy (2012), Mark Bray's Translating Anarchy: The Anarchism of Occupy Wall Street (2013), Nathan Schneider's Thank You, Anarchy: Notes from the Occupy Apocalypse (2013), and various books and articles from David Graeber (2013). More recently Farro and Demirhisar published an article on the Gezi Park movement that will also be at the basis of my analyse. Besides, the idea of a " 3 rd wave" of social 
movements was developed by Donatella Della Porta (2008). She argues that social movements have become transnational, in order to oppose globalized capitalism. Through the analysis of these publications, the presence of anarchism has been studied in the various movements of the early 2010s. By reusing Della Porta's $3^{\text {rd }}$ wave concept, this article intends to show the continuity of the movements of the early 2010s and their increasing use of anarchist - or at least anarchistic - ideas and methods. The term "anarchistic" that will be used all along this article is the translation of the French term "anarchisant" popularized by Professor Ronald Creagh. It defines a set of values or practices that are not clearly identified as anarchists but have anarchist features.

In this article, the first section presents the concept of " 3 rd wave movements" by contrasting it with other social movements analysis approaches. It gives the framework of the work that has been conducted. Using the sources mentioned above, the second section aims at making the link between modern anarchism and the $3^{\text {rd }}$ wave movements by comparing their values - in particular their political and economic values. The presence or traces of anticapitalism coupled with anti-statism could be analysed as anarchist features - or at least anarchistic features in some cases like the Arab revolutions. A third section emphasizes the anarchist traits of the methods used by some protestors in the Arab world - in Egypt and Tunisia - in Europe and in America with OWS. A final section analyses the goal of these social movements which is anarchistic, on the one hand, because it is openly and willingly leaderless and post-anarchist, on the other hand, because of the new way it defines the revolution.

\section{The Third Wave Of Social Movements: When Activism Becomes Global}

Two major approaches exist to analyse social movements (Davis, 1999; Wieviorka, 2012): The Political Opportunity Structure (POS) and the New Social Movements (NSM). The POS insists on the institutionalization of the social movements. It was adapted to the civil rights movements that occurred in the U.S. during the 1960s. These movements intended to integrate various groups like the black population, Latinos, and Native Americans, into the political system. The NSM, on the other hand, insists on the autonomy of the social movements. It was forged by Alain Touraine after the 1960 s and aimed at studying new kinds of movements within post-industrial societies. It did not focus much on their politico-economic aspects, but rather on the social and cultural ones (Touraine, 1985). However, the anti-neoliberal and the pro-democracy movements that emerged since the end of the 1990s made demands that are anchored within the political and economic fields. These movements thus need a new framework to be analysed.

As early as 1999, Davis perceived this need for a new approach. She offers a very detailed method based on the notion of "distance from the state": the distance of engage- 
ment with the state (Davis, 1999: 601). She points out four different ways for an individual to be distanced from the state either intentionally or unintentionally: geographically, institutionally, culturally, or by class. The same year saw the emergence of the Seattle protests, which constitute a milestone in the history of social movements. Donatella Della Porta uses this event as a landmark since she refers to a "post-Seattle period", which she calls a "third wave "of social movements (Della Porta, 2008). Such third wave comes after the first wave, represented by the 1960s movements, and the second wave, which are the post-60s new social movements.

This very period represents the rise of alter-globalization. During the same years, anthropologist and anarchist David Graeber describes his activism, which started with the Seattle protests. He then participated in the Global Justice Movement which he considers to be based on anarchist principles (Graeber, 2013 : 192). Finally, he took part in the Direct Action Network: a movement that developed during the Seattle protests and lasted a couple of years roughly until 2001. It opposed corporate globalization and was affiliated with some anarchist groups. Thus, the history of alter-globalization and postanarchism shared connections long before the 2010's events. A question arises from this observation: is alter-globalization the new face of anarchism?

The Seattle protests, which represent the starting point of the new wave of social movements, proceed from the many anti-neoliberal movements of the 1990s. It includes the indigenous movements all across the American continent, North and South (Della Porta, 2008; Albertani, 2012; Altmann, 2014 :12). The Zapatista Army of National Liberation (Ejército Zapatista de Liberación Nacional, EZLN) for instance, is not a mere indigenous rights movement. It has been attractive for those who oppose capitalist devastation by denouncing and seriously criticizing the economic system. It was launched deliberately the very day when the North American Free Trade Agreement (NAFTA) came into force. Similarly, the Arab Spring is the result of a long process that started many years before 2010 (Salam, 2015 : 124). Various global social forums allowed activists from many countries - including Arab ones - to gather and share ideas and methods about alter-globalization practices. Similarly, the first Maghreb social forum was organized in Morocco in 2008. It was followed by two other sessions in 2009 and 2014. Thus, it is the combination of national and international crisis contexts that allowed the Arab Spring movements, and the other global movements that followed, to take place. Indeed, the Arab Spring started with the Tunisian Revolution, which was directed against neoliberalism - as well as against the political regime. Tunisia then inspired the other Arab revolutions, even though not all of them were anti-neoliberalSyria and Libya for instance arose mostly for political reasons.

\section{Anarchism and the Third Wave Movements: Shared Values}

As mentioned above, the $3^{\text {rd }}$ wave movements' core values are political and economic. On the political level these movements proceed from peoples' distrust in the ruling elite 
and political systems. In Europe and in North America this brought what is called the crisis of representative democracy. In these countries, the lack of interest in the political system and political life has been growing these past years. Initiatives and movements opposing the national government and EU policies have preceded the Indignants and the Occupy Wall Street (OWS) movements (Pleyers, 2012). In the US, there was a certain sense of hope about Obama's presidential election.

There were people passionately committed to the idea it should be possible for progressive policies to be enacted in the United States through electoral means. Obama's failure to do so would seem to leave one with little choice but to conclude that any such project is impossible. (Graeber, 2013 : 96)

In 2008, President Obama was elected with a fully Democrat Congress ${ }^{2}$. The following disillusion of a certain part of the American population had a catalytic role in the later success of the OWS movement. In the Arab world, the people's distrust in the elites including the political elites - became manifest by the reject of authoritarian regimes. Mohammed A. Bamyeh spent a lot of his time in Tahrir Square during the first five weeks of the Egyptian uprising. He explains the difficulty of defining what 'regime' means to the people. Some use the word to refer only to the head of the state; others refer to the whole institutional system (Bamyeh, 2013 : 195). In both cases 'regime' indicates the speaker's intention to put an end to dictatorship. However, the ideology behind it is quite different. It can be either moderate or radical in its aspirations, aiming at replacing the head of state or modifying the whole system. Moderate protestors would aim at putting in place a more democratic institutional political system. The more radical protestors would yearn for a new kind of political system, less centralized. So, even though not unanimously, the idea of a rejection of the institutions was already present in Egypt.

The 'distance from the state' concept, initiated by Diane E. Davis, will be reused here in order to draw a parallel with anarchism. The idea is that the social actors who participated in one of the $3^{\text {rd }}$ wave movements have all been distanced from the state, though not in the same way. Thus, the actors of the Arab revolutions were distanced from the state by class, feeling the oppression of a ruling elite-political, military or economic through crony capitalism. The actors of the Indignants and the OWS movements - in Europe and in North America - were distanced institutionally, feeling unconcerned by the political life and neglected by politicians. To a lesser extent, the actors of these two movements may also be considered distanced from the state by class, since there is a feeling that the political elite and the economic elite are closely related (e.g. the OWS slogan "we are the $99 \%$ "). Finally, the actors of the protests in Latin America, including the more recent Brazil protests, may fall in the distanced geographically category. According to Davis, the marginalization of some people from the state pushes them to engage themselves in local collective actions and to challenge the national state (Davis, 1999).

2 Both Houses had a democrat majority from 2007 until the midterm elections of 2011. 
Challenging the state is one of the two basic principles of anarchist ideology, which are anti-capitalism and anti-statism. Mikhail Bakunin, one of the major $19^{\text {th }}$-century anarchist theorists, defends his anti-statist position by opposing statism to freedom. He argues that it is illusionary to think that the State's role is simply to ensure that people are good to each other. For no state can legislate that people should be good, given that the consciousness of good and evil depends on the moral and intellectual powers at work within each individual.

Even when the State commands the good it brings forth evil; for every command slaps liberty in the face; because when the good is decreed, it becomes evil from the standpoint of human morality and liberty. Freedom, morality, and the human dignity of the individual consist precisely in this; that he does good not because he is forced to do so, but because he freely conceives it, wants it, and loves it. (Dologoff, 1971 : 240)

Moreover, Bakunin calls in question the principle of inheritance fostered by the State because, to him, it perpetuates the social and economic inequalities. More recently, American linguist and anarchist Noam Chomsky rose up against the control the state has over the mass through media propaganda (Chomsky, 2002). He created, along with Professor Edward S. Herman, a propaganda model in order to show how mass media, controlled by an economic and political elite, can influence public opinion at a national level. Thus, there is a political set of values shared by traditional and modern anarchism and the social movements of the 2010s.

Anarchism aims at putting in place a more direct and local type of democracy, as opposed to a centralized state or authority. The so-called crisis of representative democracy, which has been happening mostly in the North, can be seen as a manifestation of anarchistic ideas. Indeed, among left-wing ideologies, both communism and socialism stand for a strong state. In the Arab countries, the identification of these two types of democracy is less easy. The opposition to an autocratic system to the benefit of a more democratic one leaves few spaces to discuss which type of democracy should be chosen afterwards. However, Bamyeh argues that the ideas of anarchism are already present in the Arab culture and its demand for a civic society through the concept of shari'a which is a "quasi-anarchist project" without state imposition (Bamyeh, 2012). In all cases, the key features of the political organization defended by anarchism are a more direct and local democracy. The $3^{\text {rd }}$ wave movements have been relying on those principles, not necessarily being aware of their anarchist implications. A movement such as anarchism possesses many theoretical and practical examples of community organization that could be used by $3^{\text {rd }}$ wave movements' protestors in order to go beyond experiences that have already been conducted.

Besides the consistency of their political claims, the movements of the $3^{\text {rd }}$ wave also shares a number of economic values. They can be seen as a continuation of the antineoliberal movements that emerged throughout the globe since the 1990s. The latter include the previously mentioned EZLN in Mexico, Global Justice Movement, Direct 
Action Network, and the various Social Forums organized all over the world. Compared with the $3^{\text {rd }}$ wave movements, anarchism opposition to the dominant economic system has a much longer history, dating back to the origins of the movement in the middle of the $19^{\text {th }}$ century. Must we recall here that the $1^{\text {st }}$ International was driven by the ideas of Marx, Engels and Bakunin? The economic position of anarchism and communism are obviously very close - the two diverging fundamentally on the political and social alternatives to put in place in order to bring forth their economic ideal. As critics of capitalism, the anarchists are very much inclined to follow Capital written by Karl Marx. The notion of "capital gain" is developed in the book. Anticapitalism is at the very roots of the anarchist ideology because of the reject of the idea of profits. Kropotkin, the father figure of anarchism, developed an economic theory in which the core value is no longer benefits but human needs. He calls this the 'science of social physiology' (Kropotkine, 2001: 50). The idea is that the economic system should be organized according to the need of the population (i.e. consumption) and not the need for profits (i.e. production).

According to Chomsky, from the 1980s until the recent protests that occurred during the 2010s, very few mass movements have opposed the dominant economic system. In Chomsky's own terms: "In both cases, in Egypt and the United States, and in fact much the world, what's happening is a reaction - in my opinion a much too-delayed reaction - to the neoliberal policies of roughly the last thirty years" (Chomsky, 2012: 62). In some Arab countries - Tunisia, Egypt, Yemen for instance - , neoliberalism was able to settle easily thanks to so-called crony capitalism (Cole, 2011; Saleh et. al., 2014). This is a type of capitalism, which works than to good relationships between the business and political elites of a given country. The authoritarian regimes of these countries welcomed the development of neoliberalism that caused an uneven repartition of wealth. Walter Armbrust, lecturer in Modern Middle East Studies at Oxford University, states for example that in Egypt: "[high-ranking members of the government] were enriched through a conflation of politics and business under the guise of privatization. This was less a violation of the system than business as usual. Mubarak's Egypt, in a nutshell, was a quintessential neoliberal state" (Armbrust, 2011). The economic inequality created by neoliberalism was one of the factors that led to the revolutions in Tunisia (Honwana, 2013), Egypt (Armbrust, 2011) and Yemen. Indeed, supply-side economics advocates the conquest of new markets in order to strengthen the economic growth. In Europe, the anti-capitalist roots of the Indignant's movement are much clearer. As a matter of facts, far-left political parties and organizations openly criticizing the capitalist system has existed for decades - the NPA in France, the Red-Green Alliance in Denmark, the Galician Nationalistic Bloc in Spain and many more.

In the United States, the world's leading capitalist economy, the situation is very different, especially in terms of anti-capitalist history. However, according to Graeber, the situation is evolving. 
In 2008, $15 \%$ felt the United States would be better off adopting a Socialist system; three years later, the number had gone up, to one in five [...] Among Americans between fifteen and twenty-five, a plurality did still prefer capitalism: $37 \%$, as opposed to $33 \%$ in favour of socialism. (The remaining $30 \%$ remained unsure). (Graeber, 2013 : 93)

One third of the American youth would be opposing capitalism according to this study. This constitutes evidence of why the OWS movement met such a success.

More recently, movements that can be included in this $3^{\text {rd }}$ wave happened in Brazil and in Turkey in 2013. The anti-neoliberalism characteristic of the period can be observed once again in both cases. In an article about the Gezi Park movement in Turkey, Farro and Demirhisar (2014) reaffirm the questioning of both the institutions and capitalism by the participants. A group called Muslim anti-capitalists is also mentioned. It shows the penetration of anti-capitalist ideas and its ability to be relevant in a variety of cultural contexts. It has to be noted that, nowadays, anarchism is far from being the only ideology which opposes capitalism - among others are Marxism, Trotskyism, and some other forms of socialism. However, the presence of anticapitalism, under the form of anti-neoliberalism, in the $3^{\text {rd }}$ wave movements when coupled with a certain sense of anti-statism suggests a certain form of proximity with anarchist ideas and ideals.

\section{Third Wave Movements: An Anarchist Method}

In an article dealing with the methods of protest used during the Arab revolutions, Bamyeh shows the definitely anarchistic style of their emergence (Bamyeh, 2013). His arguments lie primarily in the spontaneity and the absence of leaders during the various waves of protests. The Arab Spring was the result of a popular uprising and did not follow any kind of planned trajectory that could have come from a party or a political organization. However, Bamyeh warns us not to draw too strong a link between anarchism and the Arab Spring in terms of goals and demands: "The explicit goal of all Arab revolutions is the establishment of a liberal state - a civic state - not an anarchist society" (Bamyeh, 2013 : 198). Thus, the confusion must not be made between the method and the ideal of the $3^{\text {rd }}$ wave movements. It is especially true when it comes to the Arab revolutions where the anti-statist positions did exist but did not represent a majority.

In terms of methods, the use of social media is an innovation that is characteristic of these movements. They already have largely been academically studied, especially in the context of the Arab Spring (Chorev, 2012; Tudoroiu, 2014). The Occupy movement also made great use of the social media (Juris, 2013). They used them for internal communication between activists within a same city or to communicate with other Occupy camps all over the country, or even the planet. Among others, InterOccupy.org has been a very useful tool of internal communication. The advantage of social media and the Internet is that it allows the spreading of ideas and means of action in the global North as well as in the global South. Modern anarchism, since the 1990s, has also used the 
Internet and the social media to organize anarchists reading groups, anarchist cafes, anarchist book fairs and many other events of the same type. Since the 1990s, it has also developed initiatives such as CrimethInc and Indymedia (Independent media center). CrimethInc is a collective that allows the circulation of freely available publications. Indymedia, was originally founded to support the WTO protest of Seattle in 1999. It is a website that allows the democratic open-publication of stories, articles or events (Amster, 2012: 39-42). Social media allow individuals and groups to share ideas and means of action outside of any political structure. This implies an organization of small and independent groups of action which communicate with one another but do not work under any centralized authority. It opposes modern communism and socialism, which remain very structured, even beyond borders - for instance the Party of the European Left and the Party of European Socialists. From this perspective, social media allow a more anarchistic way of organizing movements.

From a more properly ideological perspective, the question of political violence can be addressed when it comes to linking social movements to anarchism. However, as already mentioned, modern anarchism especially emphasizes the opposition to the state and to the current economic system. Michel Wieviorka contends that the 2010s social movements were essentially pacific. However, he also states that: "violence takes place at the margin - where the place of a programme or vision for the future is taken over by ideology, the desire for revolution or anarchy" (Wieviorka, 2012 : 18). Yet modern anarchism does not resort to violence as it used to do at the end of the 19th century3. Anarchism, or traces of anarchism, can be found in almost every movement belonging to the $3^{\text {rd }}$ wave; and yet violence has not been a key point of these movements. Still, there must be a difference between anarchism and anarchy. If we assume that anarchism is a political philosophy, then anarchy refers to the concrete living conditions under such a political system. This is what we shall look into in the next paragraphs'.

Finally, internationalism is a key notion in anarchist ideology. Although anarchism is not the only ideology which aims at expanding all over the world, its originality lies in its advocating for internationalism to the detriment of nationalism. This vision opposes, for instance, communism which advocates internationalism for the spreading of the communist ideology but divides the world into bordered areas, not to call them countries, when it comes to organizing its territory. A good example of this is the division of the USSR into Soviet Socialist Republics - not to mention the many satellite states. Anti-neoliberal protestors of the 1990s already had this idea in mind. It is incidentally noticeable in the names of the organizations created at the time: the Global Justice Movement and the Global Day Action for instance. Graeber regards them as manifestations of anarchism. More recently, the social actors of the Arab Spring in

3 Even then, the use of violence did not represent a majority position within the movement, many theorists of anarchism rejected it.

4 The analysis of these living conditions may help to establish the presence or absence of violence in the anarchist practices as reflected in the protest movements of the 21 st century. 
some countries - Egypt and Tunisia for instance - have had some relations with the European movements and OWS groups. Even though their main goal was national, they were aware of the global extension of their activities. The interaction continued until 2013. Protestors of the Gezi Park movement felt in touch with other movements such as the Spanish Indignants (Farro \& Demirhisar, 2014) and the Occupy groups that are still active. However, among these movements, OWS is the only one which has developed a global vision of their anti-systemic claims. Indeed, OWS groups were created all around the US within a few weeks after the launching of the occupation in Zuccotti Park, New York. It took less than a year to spread all over the world and to achieve a climax with the global demonstration day of October 15, 2012. That day, protests took place in 951 different cities in 82 countries (Akbaba, 2013). By achieving such a goal, OWS concretized the internationalist vision of anarchism. More than just a practical achievement, OWS produced a theoretical analysis of this internationalism through a text, the Occupy Global May Manifesto. The anarchistic flavour of this text is clearly noticeable: "We do not make demands from governments, corporations or parliament members, which some of us see as illegitimate, unaccountable or corrupt. We speak to the people of the world, both inside and outside our movements."

\section{The Ultimate Goal of the 3rd Wave Movements: Set an Example}

What is discussed here concerns the ultimate goal of these social movements and their degree of attachment to the anarchist ideal. Can we call these movements "revolutionary" or are they just "social movements"? In order to answer this question we must first establish the basic difference between the two. According to Davis, a social movement concerns: "collectively organized actors who are removed enough from the state to mobilize and make demands on it, but not so distanced that tearing it down is the preferred option" (Davis, 1999: 619). Davis definition points out the difference between a social movement and a revolution. The Arab Spring, on the one hand, and the Indignant's movement and the OWS movement on the other are quite different in terms of goals and demands - notwithstanding the diversity of the demands of the Arab revolutions. Protests in Europe and North America would never have turned to revolutionary movements. As Chomsky emphasizes:

To have a revolution - a meaningful one - you need a substantial majority of the population who recognize or believe that further reform is not possible within the institutional framework that exists. And there is nothing like that here, not even remotely. (Chomsky, 2012 : 59)

His analysis is centred on the United States but he makes a point that is transferable to the rest of the global North. In these countries, representative democracy is the political standard. The social movements, which occurred there, were much more inclined to reject neoliberalism and capitalism than they were to destroy the nation-state or change its institutional system. Consequently, there is no majority in the population of the northern countries to follow the path of revolution. 
In the Arab world, it is less clear whether the protestors aimed at conducting a social movement or a revolution, even though the protests were clearly directed against the ruling elite - political or economic. On the one hand, Wieviorka rejects the idea of revolutions. He states that the social actors demanded more social justice and more democracy but had no will whatsoever to take hold of power.

These actors indicate the mobilization of generations who were not involved in politics, distrusted it or were not interested in it, who wish to participate in the life of the City in a different way. They do not want to be involved in parties and classical forms of mobilization and so those who contribute to the re-enchantment of democracy by inventing new forms of participation and deliberation. (Wieviorka, 2012:16-17)

The actors of some of the Arab Spring like Tunisia, Egypt and Yemen did want to change the institutions, if not by force, at least by establishing a new type of government. In Egypt, in Yemen and in Tunisia, this change did eventually happen, even for a short period of time. So, even though the original aim of the Arab Spring was not revolutionary, that is what it turned out to be in some of these countries. It is especially true if we borrow Davis's definition of revolution. She describes a revolution as a moment when tearing the state down is the preferred option (Davis, 1999: 619). Indeed, the term "revolution" is omnipresent throughout an article from Bamyeh on the Egyptian protests and the Arab Spring (Bamyeh, 2013).

The will of the social actors of the 2010s movements to oppose or reject the institutions puts them, at times, in an ambiguous position, especially when it comes to the sustainability of their action. Indeed, they are unable to negotiate with the institutions they reject, because of an ideological refusal (Pleyers \& Glasius, 2013 : 74). Pleyers and Glasius think of it as a weakness, or a limit to the power of action of these mobilizations. However, in terms of anarchist practices, the incapacity of these movements to designate representatives to negotiate with the institutionalized states is simply not among their preoccupations. In the same article, Pleyers and Glasius underline that the activists spend an ever-growing part of their time organizing the movement and the occupied space. This is what differentiates these movements from former non-anarchist ones. The political and economic demands, previously discussed, are certainly a crucial point but they cannot be the only one. In this line, the ultimate goal is not to change society through the institutions but to change the institutions themselves. In order to do so, the 2010s movements strove to be an example for other anarchistic manifestations throughout the world - even though, of course, the word "anarchism" itself does not appear that often.

The first way to stand as an example is to show that a different type of democracy is possible and can work for a large number of people and not only at a community level'5.

5 Most practical economic and/or political alternative experiments, since the emergence of alterglobalization, have been conducted at a local level. 
The type of democracy advocated by the $3^{\text {rd }}$ wave movements, and defended by anarchists for over a century, is direct democracy. In the past few years, the demand for direct democracy has developed alongside alter-globalization protests. More recently, it has been used by many of the $3^{\text {rd }}$ wave movements including the Arab Spring, the Greek and Spanish Indignants, OWS, and even later movements such as the Gezi Park in Turkey (Khosrokhavar, 2012; Graeber, 2013; Farro \& Demirhisar, 2014). Direct democracy advocates the self-management of collectives. It uses a number of specific tools such as general assemblies, consensuses, and horizontalism (Cornell, 201: 2). Movements organized in such a way purposefully do not designate any leader or representative. They do not seek political representation or the creation of a political party. The use of this type of democracy within the $3^{\text {rd }}$ wave movements is scarcely associated with anarchism by the protestors. A greater awareness of it would open up the protestors to a whole theoretical background about alternative political organization.

Even though the Arab Spring ended up challenging the authoritarian regimes in place - with more or less success - , the original aim of the social actors who participated in these movements was not to take over power (Wieviorka, 2012 : 18). Indeed, the absence of leaders in the movement itself was a step towards a new kind of political organization, without any leaders. There was almost no organization in some cases like in Tunisia or Egypt. The protest movements came from "the little person, not the historical figure, the hero, or the savior" (Bamyeh, 2013: 198). Once again, this is a very anarchistic position. The OWS movement was much more influenced by modern anarchism from its very beginning. It made a point, as well, not to designate any leading figure or spokesperson. David Graeber, for instance, who was a key organizer of the movement and wrote abundantly about it, did not feel like it was his place to become a figure of the movement: "Myself, I've never been much of a rabble-rouser. During the entire time I'd been involved in Occupy, I'd never once made a speech" (Graeber, 2013 : xi) he said. Noam Chomsky, famous for his anarchist commitment since the 1970's, gave a few speeches, in particular at Occupy Boston. However, he did not participate in the actions as much as Graeber. He was thus more in a position to give his opinion from the outside rather than trying to lead anything. On October 22, 2011, he spoke at Occupy Boston:

My voice wouldn't help. And besides, you don't want leaders; you want to do it yourselves. [Applause and cheers] We need representation, but you need to pick them yourselves and they need to be recallable representatives. We're not going to fall into some system of control and hierarchy. (Chomsky, 2012: 43)

Such a position coming from Graeber and Chomsky, is not at all surprising - given that they embrace the anarchist ideology. What was less expected was the popular reaction to this no leader position. The idea was to demand a new kind of political organization. In order to put in place such an organization, the protestors wanted to show, by experiencing it, that it was achievable on a large scale, which they did. The rejection of representatives in the North and the rejection of the autocracies in some countries of the 
Arab world-Mubarak, Ben Ali and Saleh for instance-shows this leaderless allure even if the connection between what is opposed and what is proposed is not always so clearly presented by the protestors. Indeed, what these Arab revolutions may have lacked could be a clearer link between their political aspirations - the development of a civil government with leaders elected - and their revolutionary methods - that were often leaderless.

Another way of being an example for the rest of the world and for the future social movements was to propose concrete alternatives to capitalism. These alternatives developed at a much larger scale within the European and North American movements (Pleyers \& Glasius, 2013 : 71). The social actors organized different types of alternatives. For instance, they developed projects of social economy, they tried to establish organizations or cooperatives with a non-profit and social aim. These already existed before the $3^{\text {rd }}$ wave movements but may not have been as recognized as they are now. Another type of alternative was the creation of a local independent currency. To challenge the idea of national currency - or even the idea of currency itself - has been an idea and goal of anarchism since its very beginning (Reclus, 1998: 157). Several reasons could explain the lack of economic alternatives developed in the Arab world, compared to what happened in the global North. First, one can mention the lack of a functional civil society, due to a lack of free speech. In the North, for example, some groups had been putting in place such alternatives for a few years - and even a few decades for some of them. In the Arab countries most impacted by neoliberalism-Tunisia, Egypt and Yemen for instance - there was a lack of economic alternatives. Second, the national framework of the subversive critic is much stronger in the Arab world. In Egypt, Tunisia and Yemen, the emphasis is put on opposing the authoritarian political regime and the economic elite both at the same time. And this makes sense in a context of crony capitalism. Finally, the organization of economic alternative projects in the North is the result of the destruction of the local economy and of the urbanization and centralization of economic activities. This process being less advanced in the Arab world, the building of such alternatives may seem less primordial - especially when compared to the overthrow of dictatorships.

These two ways of setting an example, of living change rather than just demanding it, or demonstrating for it, show another innovation in the $3^{\text {rd }}$ wave movements. This innovation is characteristic of anarchism's anti-systemic approach. The idea of class is not as strong as it was in the 1960s and before, when Marxism had more influence over subversive movements. The end of the Cold War, by the end of the 1980s, opened up a new period for social movements in which the ideas of the proletariat and the class struggle, characteristic of communist ideology, started to decline. Instead of a class struggle, which opposes the hegemony of a politico-economic ruling elite, an anti-system struggle arose. It opposed at once the political and the economic systems, namely representative democracy and capitalism. Wieviorka perceives this shift in opposition when he talks about "actors incapable of designating a social class adversary, or more 
important, do not even wish to do so" (Wieviorka, 2012:15). The opposition is direct against the institutions and no longer against people, i.e. an upper, or ruling, class. Economically, opposing the capitalist system is something communism and anarchism have in common. Opposing representative democracy in the way $3^{\text {rd }}$ wave protestors implies a certain opposition to the idea of the nation-state which communism does not share with anarchism. The anti-systemic dimension of the $3^{\text {rd }}$ wave movements is very anarchistic, ideologically. Farro and Demirhisar (2014) have written about the collective actions against systemic domination and analysed these actions as aiming at regenerating the institutional system. Besides, if anarchism is still regarded as violent today, it is because it advocates the destruction of the state and the destruction of the capitalist system. However, destruction is not seen as an end, but as a means to rebuild something judged "better" on the ashes of the old system. This destruction can take the form of a social revolution as it was advocated by anarchist ideology in the $19^{\text {th }}$ and early $20^{\text {th }}$ centuries. It may also be the result of a multiplicity of small local actions, as post-anarchism advocates today. The redefinition of the concept of revolution has been developed by modern thinkers these past few decades. John Holloway is a good example of this second approach to destruction. He argues that global change is only possible thanks to all the individuals who participate in alternative projects and use, as much as they can, all the little "cracks" that exist in the capitalist system (Holloway, 2010). This dual concept of destruction/reconstruction cannot be split into two and could be resumed in one word: transformation or even regeneration. Thus, the shift from a dominant system to a newly established one under the form of regeneration is nothing new and fits in the post-anarchist ideology.

\section{Conclusion}

The revival of anarchism under the form of post-anarchism coincides with the rise of alter-globalization in the 1990s. Both movements correspond to a reaction to the neoliberal policies conducted since the 1980s. They have been linked for over two decades in their theory, and in their practice. The movements that emerged at the beginning of the 2010s bore traces of this link. Thus, if OWS had so many anarchist features in itself, it is probably because of several factors. On the one hand, there is an American anarchist background that has been growing since 1999 and the Seattle protests. On the other hand, OWS has taken ideas from the Indignants and the Arab Spring movements - mainly in Tunisia, Egypt and Yemen where the demands were both political and economic - , which, in a more limited way, had also been influenced by anarchism.

The word "anarchism" does not appear that much in the context of $3^{\text {rd }}$ wave movements, especially in mainstream media. However, in terms of theoretical ideas and actual practice, what anarchism advocates lives through alter-globalization and anti-neoliberalism and the alternatives projects they put in place. It does so thanks to the transmission of its ideals from one social movement to the next throughout history 
until today. Nevertheless, it could be argued that the efficiency of these movements would be greater were they aware of their anarchistic features, thus being able to tap into anarchist history and literature. Where antistatism is coupled with anticapitalism - antineoliberalism - it is thus possible to talk about anarchist features, or anarchistic features. The 2010s social movements can be seen as a chain, each in interaction with the next one. Consequently, anarchism within the movements of the 2010s started growing from the Arab Spring - in Egypt and Tunisia - , through the Greek protests and the Indignant's movement, until it reached a climax with OWS. Thus, the $3^{\text {rd }}$ wave movements and more recently the 2010s movements, seem to have participated in the emergence of modern anarchism which gave rise to a global politico-economic experiment: the Occupy Wall Street movement.

\section{Bibliography}

AквавA C. (2013), "Occupy the world: The emergence of an international movement », Middle Eastern Analysis, vol. 5, n 57, p. 28-34.

Albertani C. (2012), Le miroir du Mexique, Paris Éditions du monde libertaire.

Altmann, P. (2014), « Una breve historia de las organizaciones del Movimiento Indígena del Ecuador », Antropología. Cuadernos de Investigación, n 12, p. 1-17.

AMSteR R. (2012), Anarchism today, Santa Barbara, Praeger.

ANDERSON L. (2011), « Demystifying the Arab Spring: parsing the differences between Tunisia, Egypt, and Libya », Foreign Affairs, p. 2-7.

ARMBRUST W. (2011), «Egypt: A Revolution against Neoliberalism?», Al-Jazeera, February, 24 .

BAMYeH M. A. (2013), « Anarchist Method, Liberal Intention, Authoritarian Lesson: The Arab Spring between Three Enlightenments », Constellations, vol. 2, p. 188-202.

Bamyen M. A. (2012), « Anarchist Philosophy, Civic Traditions and the Culture of Arab Revolutions 1. Middle East Journal of Culture and Communication », vol. 5, n 1, p. 32-41.

BRAY M. (2013), Translating anarchy: The anarchism of Occupy Wall Street, Washington/Winchester, John Hunt Publishing.

Chomsky N. (2002), Understanding Power: The Indispensible Chomsky, New-York, New Press.

Chomsky N. (2012), Occupy, Brooklyn, Zuccotti Park Press.

CHOREv H. (2012), « The spring of the networked nations: Social media and the Arab Spring », The Levantine Review, vol. 1, n ², p.120-139. 
COLE J. (2011), « How neoliberalism created an age of activism », Al Jazeera, 15.

Cornell A. (2013), « Occupy Wall Street and Consensus Decision Making: Historicizing the Preoccupation With Process ». Is This What Democracy Looks Like? En ligne. URL : http://what-democracy-looks-like.org/occupy-wall-street-and-consensusdecision-making-historicizing-the-preoccupation-with-process/.

DAVIS, D. E. (1999), « The power of distance: re-theorizing social movements in Latin America », Theory and Society, vol. 28, $n^{\circ}$ 4, p. 585-638.

Della PorTa D. (2008), «L'altermondialisme et la recherche sur les mouvements sociaux. Quelques réflexions », Cultures e`Conflits, $\mathrm{n}^{\circ}$ 70, p. 13-31.

Dolgoff S. (dir.) (1971), Bakunin on Anarchy, New-York, Vintage books.

FARRo A. L., \& DeMirhiSAR D. G. (2014), « The Gezi Park movement: a Turkish experience of the twenty-first-century collective movements », International Review of Sociology, vol. $24, \mathrm{n}^{\circ} 1$, p. 176-189.

GRAEBER D. (2013), The democracy project, New-York, Spiegel \& Grau.

Holloway J. (2010), Crack Capitalism, London, Pluto Press.

Honwana A. (2013), Youth and revolution in Tunisia, London, Zed Books.

JURIS J. (2013), « Global Justice and Occupy Movements: Technology, Social Media, and Emerging forms of Mobilization ", Reclaiming Democracy and Social Justice: From the Arab Spring to Occupy to ... (International Conference at the Centre for Studies in Social Justice, University of Windsor, ON, May 2013).

KHOSRokhaVar F. (2012), The new Arab revolutions that shook the world, Boulder, Paradigm Publishers.

Kropoktine P. (2001), Euvres, Paris, La Découverte.

Pleyers G. (2012), “Alter-Europe: four ways to deal with the crisis of representative democracy”, Vlaams Marxistisch Tijdschrift, vol. 46, n 4, p. 27-32.

Pleyers G., Glasius M. (2013), « La résonance des «mouvements des places» : connexions, émotions, valeurs », Socio, vol. 2, p. 59-79.

RECLUS E. (1998), L’homme et la Terre, Paris, La Découverte.

SALAM E. A. A. (2015), « The Arab spring: Its origins, evolution and consequences ... four years on », Intellectual Discourse, vol. 23, n 1, p. 119-139.

Saleh S. S., Alameddine M. S., Natafgi N. M., Mataria A., SAbri B., Nasher J., Siddiqi S. (2014) « The path towards universal health coverage in the Arab uprising countries Tunisia, Egypt, Libya, and Yemen », The Lancet, vol. 383, n ${ }^{\circ} 9914$, p. 368-381. 
SchneIDER N. (2013), Thank You, Anarchy: Notes from the Occupy Apocalypse, Berkeley, University of California Press.

SMITH J. (2012), « Connecting social movements and political moments: Bringing movement building tools from global justice to Occupy Wall Street activism », Interface: A Journal for and About Social Movements, vol. 4, $\mathrm{n}^{\circ}$ 2, p. 369-382.

TOURAINE A. (1985), « An introduction to the study of social movements », Social research, vol. 52, $n^{\circ} 4$, p. 749-787.

Tudoroiu T. (2014), «Social media and revolutionary waves: The case of the Arab spring », New Political Science, vol. 36, n 3, p. 346-365.

WIEVIORKA M. (2012), « The resurgence of social movements », Journal of Conflictology, $\mathrm{n}^{\circ} 2$, p. 13-19. 